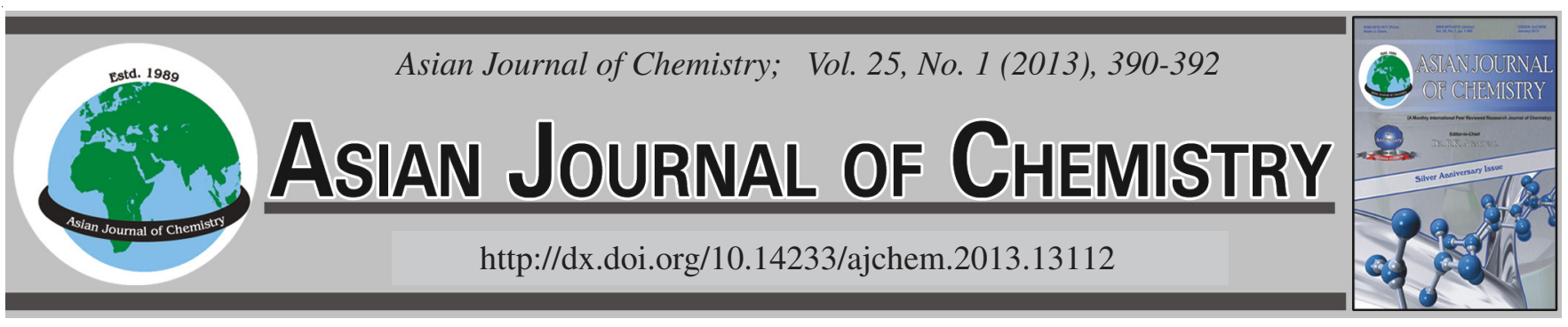

\title{
Hydrodistilled Volatile Oil from Stems of Eryngium creticum Lam. in the Marginal Brackish Regions of Semnan Province by Using Gas Chromatography Combined with Mass Spectrometry
}

\author{
Majid Mohammadhosseini
}

Department of Chemistry, Shahrood Branch, Islamic Azad University, Shahrood, Iran

Corresponding author: Fax: +98 273 3394537; Tel: +98 273 3394530; E-mail: majidmohammadhosseini@yahoo.com; m_mhosseini@iaushahrood.ac.ir

\section{INTRODUCTION}

The genus Eryngium belongs to Apiaceae family and consists 9 thorny species in Iran. Among them, E. bungei, E. caucasicum as well as E. billardieri are the most common species worldwide ${ }^{1}$. The chemistry, genetic diversity and properties of several species of Eryngium have been previously studied in detail in the literature ${ }^{2-11}$. However, the essential oils of only few species have been previously reported ${ }^{12-21}$. Some of the common pharmaceutical and medical applications of the most familiar species of Eryngium genus in folk medicine are listed in Table-1. Semnani ${ }^{22}$ has reported analysis of essential oil of E. bungei Boiss. (Umbelliferae) collected from the suburb and coastal margins of Sari, North of Iran. In this work, the chemical profile of hydrodistilled volatile oil was mostly characterized by cumin alcohol $(55.3 \%)$, terpinolene $(14.6 \%)$, carvacrol $(8.9 \%)$ and limonene $(7.5 \%)$.

Nowadays, modern sample preparation in analytical chemistry is characterized by simplification, miniaturization, high enrichment and minimization of sample amount and solvent ${ }^{23}$.

The main goal of present study is to operate and optimize a simple and reliable process for the extraction of essential oil by utilization of hydrodistillation method from the fresh stems of Eryngium creticum Lam.

\begin{tabular}{|c|c|}
\hline \multicolumn{2}{|c|}{$\begin{array}{c}\text { TABLE-1 } \\
\text { COMMON PHARMACEUTICAL PROPERTIES } \\
\text { OF SOME ERYNGIUM GENUS } \\
\end{array}$} \\
\hline Eryngium genus & Applications \\
\hline E. glaciale & $\begin{array}{l}\text { Diuretic and laxative properties } \\
\text { to treat urinary ailments, edemas acidosis as } \\
\text { well as an aid to digestion }\end{array}$ \\
\hline E. caucasicum Trautv. & $\begin{array}{l}\text { Enforcing generative power, diuretic, } \\
\text { lenitive and appetizer }\end{array}$ \\
\hline E. foetidum $\mathrm{L}$. & $\begin{array}{l}\text { Food flavouring, traditional medicine for } \\
\text { colds, asthma, cough, sinusitis, rheumatism, } \\
\text { diarrhea }\end{array}$ \\
\hline
\end{tabular}

To the best of my knowledge, it is the first report of the utilization of hydrodistillation as an effective, fast and straightforward method for recognizing the volatile composition of stems of E. creticum Lam. Also, chemical composition of the volatile oil from E. creticum Lam. in Semnan province (Iran) has not been previously studied.

\section{EXPERIMENTAL}

The plant material was collected while wearing polystyrene gloves during the flowering stage in Mahishahr Mountains located in the east of Semnan Province, Iran, in May 2010, at an altitude of $1530 \mathrm{mtrs}$. Special care was taken to avoid extra damaging and minimizing cross-contamination of plant parts. 
Botanical identification: The plant was identified by a local botanist and a voucher specimen was deposited at the Herbarium of the Research Institute of Forests and Rangelands, Tehran, Iran.

Drying and hydrodistillation: Fresh stems of E. creticum Lam. were air-dried in the shade at $25^{\circ} \mathrm{C}$ for one week, cut into pieces of size over the range $1-4 \mathrm{~cm}$ and grounded to a homogeneous powder. The powder was immediately placed in a $2 \mathrm{~L}$ round bottom flask containing an adequate amount of distilled water for the plant material to be completely immersed. Afterwards, hydrodistillation was conducted on $150 \mathrm{~g}$ portion of the stems powder by using a typical Clevenger-type apparatus to produce oils lighter than water ${ }^{24}$. The collection of the oil was terminated when no increase in essential oil level was observed for longer than $1 \mathrm{~h}$, with total distillation times between 2 and $3.5 \mathrm{~h}$.

The corresponding pale yellowish oil was recovered in yield of $0.18 \%$ (w/w) and was dried over anhydrous sodium sulfate, weighed and kept in a tightly Teflon-capped amber vial at $-10{ }^{\circ} \mathrm{C}$ until analysis with a meticulous care.

Chromatographic analysis: Gas chromatography analysis was performed on a Shimadzu 15 A gas chromatograph equipped with split/splitless injector $\left(250^{\circ} \mathrm{C}\right)$ and flame ionization detector (FID) at $280{ }^{\circ} \mathrm{C}$. Nitrogen of high-purity was used as carrier gas at a flow rate of $1 \mathrm{~mL} / \mathrm{min}$. A SE 30 column $(50 \mathrm{~m} \times 0.2 \mathrm{~mm})$ with film thickness of $0.3 \mu \mathrm{m}$ was employed for separation of the constituents. The column temperature was kept at $90{ }^{\circ} \mathrm{C}$ for $3 \mathrm{~min}$, then increased to $220^{\circ} \mathrm{C}$ with a $5{ }^{\circ} \mathrm{C} / \mathrm{min}$ rate and kept constant for $5 \mathrm{~min}$ at final temperature. Relative percentages were calculated using a Shimadzu C-R4A Chromatopac and peak area was taken into consideration.

A Hewlett-Packard 6890/5973 apparatus fitted with a HP-5 MS column $(30 \mathrm{~m} \times 0.25 \mathrm{~mm}$, film thickness $0.25 \mu \mathrm{m})$ was used. The column temperature was kept at $60^{\circ} \mathrm{C}$ for $3 \mathrm{~min}$ and programmed to $220^{\circ} \mathrm{C}$ at a rate of $5{ }^{\circ} \mathrm{C} / \mathrm{min}$ and kept constant at $220^{\circ} \mathrm{C}$ for five min. Helium was the carrier gas (1 $\mathrm{mL} / \mathrm{min})$. The split ratio was 1:50. The MS spectrometer was fitted with an electron impact (EI) source operated at an ionization potential of $70 \mathrm{eV}$ with an ion source temperature of $200^{\circ} \mathrm{C}$ and a resolution equal to 1000 . All the mass spectra were recorded in the range of $\mathrm{m} / \mathrm{z}$. 30-500 amu in the fullscan acquisition mode. The interface temperature was $280{ }^{\circ} \mathrm{C}$. The hexanic solutions of a homologous series of saturated paraffins $\left(\mathrm{C}_{9}-\mathrm{C}_{21}\right)$ and of essential oils were analyzed in GC-FID and GC-MS, using both columns under the same conditions. The linear retention indices were calculated for all volatile components.

Qualitative and quantitative analyses: Determination and identification of the constituents of the oil were made by comparing their mass spectral fragmentation pattern concerning authentic samples and retention indices (RI) relative to $\mathrm{C}_{9}-\mathrm{C}_{21}$ $n$-alkanes with those given in the literature ${ }^{25-33}$ and data stored in a MS library (Wiley 275), as well as matching them with National Institute of Standards and Technology mass spectra library (NISTMSL) package with a resemblance percentage above $85 \%$. Relative percentage amounts of the components were directly calculated from peak area using a Shimadzu C-R4A Chromatopac on the SE-30 column, considering the sum of all eluted peaks as a $100 \%$ without the use of correction factor.

\section{RESULTS AND DISCUSSION}

The retention indices, contents and total contents of chemical compositions in essential oils obtained from stems of E. creticum Lam. are listed in Table-2. Seventeen constituents $(91.4 \%)$ were identified in this oil: four monoterpene hydrocarbons $(\mathrm{MH}=19.5 \%)$, five oxygenated monoterpenes (OM $=57.3 \%)$, five sesquiterpene hydrocarbons $(\mathrm{SH}=12.1 \%)$, two non-terpenoid hydrocarbon $(\mathrm{NH}=1.6 \%)$ and one oxygenated diterpene $(\mathrm{OD}=0.9 \%)$. Based on this information, oxygenated monoterpenes were the major constituents and a ranking order of the groups of constituents as $\mathrm{OM}>\mathrm{MH}>\mathrm{SH}$ $>\mathrm{NH}>\mathrm{OD}$ was observed in the volatile flower oil. Bornyl acetate was the most abundant constituent (28.4\%), followed by camphor $(17.8 \%), \alpha$-pinene $(12.1 \%)$, germacrene D $(9.4 \%)$, borneol $(8.6 \%)$ and $\alpha$-thujene $(4.2 \%)$.

TABLE-2

CONSTITUENTS OF ESSENTIAL OILS FROM STEMS OF Eryngium Creticum LAM. EXTRACTED WITH HD METHOD

\begin{tabular}{clcc}
\hline No. & Compounds $^{\mathrm{a}}$ & $\mathrm{RI}^{\mathrm{b}}$ & $\%$ \\
\hline 1 & $\alpha$-Thujene & 924 & 4.2 \\
2 & $\alpha$-Pinene & 932 & 12.1 \\
3 & Camphene & 946 & 1.7 \\
4 & $\beta$-Pinene & 974 & 1.5 \\
5 & 1,8 -Cineol & 1026 & 2.1 \\
6 & Camphor & 1141 & 17.8 \\
7 & Borneol & 1165 & 8.6 \\
8 & Cis-pinocarveol & 1182 & 0.4 \\
9 & Bornyl acetate & 1287 & 28.4 \\
10 & Eugenol & 1356 & 0.5 \\
11 & Coumarin & 1432 & 1.1 \\
12 & trans- $\beta$-Farnesene & 1454 & 0.3 \\
13 & $\gamma$-Himachalene & 1481 & 0.2 \\
14 & Germacrene-D & 1484 & 9.4 \\
15 & $\beta$-Selinene & 1489 & 0.1 \\
16 & $\alpha$-Selinene & 1498 & 2.1 \\
17 & Phytol & 1943 & 0.9 \\
\hline & Total & & 91.4 \\
\hline
\end{tabular}

${ }^{\text {a }}$ The compounds have been sorted according to their Kovats retention

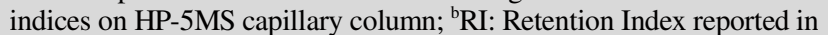
literature on DB-5 column

\section{ACKNOWLEDGEMENTS}

The author is grateful for the financially support provided by Islamic Azad Universities of Shahrood and Varamin concerning a research project entitled "Chemical Composition of the Essential oils from Some Endemic Plants of Semnan Province". Furthermore, the author expresses his special thanks to Dr. Mozaffarian for botanical identification.

\section{REFERENCES}

1. V. Mozaffarian, A Dictionary of Iranian Plant Names, Farhang Moaser, Tehran, Iran (1996).

2. D. Drake and J. Lam, Phytochemistry, 11, 2651 (1972).

3. K. Hiller, K.Q. Nguyen and P. Franke, Pharmazie, 33, 78 (1978).

4. O.R. Simon and N. Singh, West Indian Med. J., 35, 121 (1986).

5. Z. Yaniv, A. Dafni, J. Friedman and D. Palevitch, J. Ethnopharmacol., 19, 145 (1987). 
6. S. Al-Khalil, Alexendria J. Pharm. Sci., 8, 73 (1994).

7. A. Alkofahi, A.J. Sallal and A.M. Disi, Phytother. Res., 11, 540 (1997).

8. M.T. Saenz, M.A. Fernandez and M.D. Garcia, Phytother. Res., 11, 380 (1997).

9. M.D. Garcia, M.T. Saenz, M.A. Gomez and M.A. Fernandez, Phytother. Res., 13, 78 (1999)

10. E.S. Menges and J. Kimmich, Am. J. Bot., 83, 185 (1996).

11. M. Gaudeul, P. Taberlet and I. Till-Bottraud, Mol. Ecol., 9, 1625 (2000)

12. P.A. Leclercq, N.X. Dung, V.N. Lo and N.V. Toanh, J. Essent. Oil Res., 4, 423 (1992).

13. K.C. Wong, M.C. Feng, T.W. Sam and G.L. Tan, J. Essent. Oil Res., 6, 369 (1994).

14. J.A. Pino, A. Rosado and V. Fuentes, J. Essent. Oil Res., 9, 123 (1997).

15. J.A. Pino, A. Rosado and V. Fuentes, J. Essent. Oil Res., 9, 467 (1997).

16. A.P. Martins, L.R. Salgueiro, A.P. da Cunha, R. Vila, S. Canigueral, F. Tomi and J. Casanova, J. Essent. Oil Res., 15, 93 (2003).

17. M.I. Cobos, J.L. Rodriguez, A. de Petre, E. Spahn, J. Casemeiro, A.G Lopez and J.A. Zygadlo, J. Essent. Oil Res., 14, 82 (2002).

18. J.J. Brophy, R.J. Goldsack, L.M. Copeland and J. Pala-Paul, J. Essent. Oil Res., 15, 392 (2003).

19. J. Pala-Paul, J.J. Brophy, R.J. Goldsack, L.M. Copeland, M.J. PerezAlonso and A. Velasco-Negueruela, Aust. J. Bot., 51, 497 (2003).

20. F. Sefidkon, M. Dabiri and A. Alamshahi, J. Essent. Oil Res., 16, 42 (2004).

21. J. Pala-Paul, M.J. Perez-Alonso, A. Velasco-Negueruela, J. Varade, M.A. Villa, J. Sanz and J.J. Brophy, J. Chromatogr. A, 1074, 235 (2005).
22. K. Morteza-Semnani, J. Essent. Oil Res., 17, 485 (2005).

23. C. Zhang, M. Qi, Q. Shao, S. Zhou and R. Fu, J. Pharmac. Biomed. Anal., 44, 464 (2007).

24. British Pharmacopoeia HMSO, London, 2: A137-A138 (1998).

25. R.P.Adams, Identification of Essential Oils Components by Gas Chromatography/Quadrapole Mass Spectrometry, Allured Publishing Corporation, Illinois, USA (2001).

26. R.P. Adams, Identification of Essential Oil Components by Gas Chromatography/Mass Spectrometry, Allured Pubishing Co., Carol Stream, IL, USA (2007).

27. M. Mohammadhosseini, A. Pazoki and H. Akhlaghi, Chem. Nat. Comp., 44, 127 (2008)

28. H. Akhlaghi, A. Shafaghat and M. Mohammadhosseini, J. Essent. Oil Bearing Plant, 12, 365 (2009).

29. H. Akhlaghi, M.R. Saiidi-Asl and M. Mohammadhosseini, Chem. Nat. Comp., 45, 448 (2009).

30. M. Mohammadhosseini, A. Pazoki, H.A. Zamani, H. Akhlaghi and M. Nekoei, J. Essent. Oil Bearing Plant, 13, 704 (2010).

31. M. Mohammadhosseini, A. Pazoki, H.A. Zamani and H. Akhlagh, J. Essent. Oil Bearing Plant, 14, 101 (2011).

32. M. Mohammadhosseini, H.A. Zamani, H. Akhlaghi and M. Nekoei, $J$. Essent. Oil Bearing Plant, 14, 559 (2011).

33. M. Mohammadhosseini, Asian J. Chem., 24, 1432 (2012). 